dr hab. Robert Zygmunt JASTRZĘBSKI, prof. UW Wydział Prawa i Administracji, Uniwersytet Warszawski e-mail: r.jastrzebski@wpia.uw.edu.pl

ORCID: 0000-0002-7265-0614

DOI: 10.15290/OES.2021.03.105.06

\title{
PRAWO MORATORYJNE PAŃSTWA POLSKIEGO W OKRESIE KRYZYSU GOSPODARCZEGO LAT 30. XX WIEKU ${ }^{1}$
}

\author{
Streszczenie
}

Cel - Artykuł ma na celu scharakteryzowanie ustawodawstwa moratoryjnego państwa polskiego w okresie kryzysu gospodarczego lat 30. Omówiono w nim przede wszystkim ustawodawstwo w zakresie zobowiązań publicznoprawnych i prywatnoprawnych. W szczególności zwrócono uwagę na strukturę gospodarczą oraz politykę deflacyjną państwa polskiego, które determinowały ówczesną legislację.

Metoda badan - Dokonano przeglądu literatury przedmiotu oraz wykorzystano analizę przepisów prawa.

Wnioski - Wskazano, że ustawodawstwo moratoryjne dotyczyło przede wszystkim rolnictwa ze względu na strukturę gospodarczą państwa polskiego. Miało ono charakter antyegzekucyjny i polegało na obniżeniu stopy procentowej oraz rozłożeniu na szereg lat spłaty zobowiązań pieniężnych, zwłaszcza prywatnoprawnych.

Oryginalnosí / wartość / implikacje / rekomendacje - Cel i funkcje ustawodawstwa moratoryjnego miały i mają istotne znaczenie dla gospodarki, w szczególności w okresie kryzysów. Egzemplifikacją tego jest właśnie ustawodawstwo państwa polskiego, które realizowało przyjętą strategię polityki deflacyjnej.

Słowa kluczowe: wielki kryzys gospodarczy lat 30. XX wieku w Polsce, moratorium, konwersja zobowiązań pieniężnych, polityka deflacyjna, nominalizm pieniężny

\section{POLISH MORATORY LAWS DURING THE GREAT DEPRESSION OF THE 1930S}

\begin{abstract}
Summary
Purpose - The article aims at characterising Polish moratory laws during the Great Depression. The article is centred around the legislation on public and private law liabilities. The author pays particular attention to the structure of the Polish economy and to Poland's deflationary policy that determined the Polish legislation of that time.

Research method - The author reviewed the literature on the subject and analysed legal regulations.

Results - The author indicates that - given the structure of the Polish economy - moratory legislation concerned the farming industry in particular. It was mainly of an anti-enforcement nature and consisted in reducing the interest rate and spreading the debt repayment over several years (particularly as regards private law liabilities).
\end{abstract}

1 Artykuł wpłynął 17 lutego 2021 r., zaakceptowano 26 kwietnia 2021 r. 
Originality / value / implications / recommendations - The purpose and functions of moratory laws were, and still are, of particular importance to the economy, especially at the time of economic crisis. This is exemplified by the moratory legislation of the Polish State that adopted and pursued the deflationary policy.

Keywords: Great Depression in Poland, moratorium, debt conversion, deflationary policy, nominalism

JEL Classification: K12, K34, N14, N24

\section{Pojęcie moratorium}

Moratorium stanowiło i stanowi odroczenie terminu płatności lub wstrzymanie na określony okres pewnych działań ze względu na nadzwyczajne wydarzenia. Ustanawiane jest ono na podstawie aktu władzy państwowej, przy czym określenie jego zakresu w poszczególnych przypadkach może być przekazane władzy sądowniczej lub specjalnie do tego powołanym urzędom. W związku z tym moratorium oznacza zasadniczo specyficzną odmianę konwersji zobowiązań, która polega na zmianie terminu wykonania świadczeń przede wszystkim pieniężnych. Wynika z tego, że jest ono sui generis aktem władzy państwowej, na podstawie którego sa zawieszane terminy wykonania zobowiązań przez dłużników, a także dopełnienia niezbędnych czynności prawnych przez wierzycieli w celu dochodzenia ich należności, zwłaszcza dotyczy to zawieszenia lub przerwania biegu przedawnienia roszczeń [Liebeskind, 1935, s. 935-939; Glass, 1930, s. 489-492; Tennenbaum, 1936, s. 237-238].

Wydawanie moratoriów dotyczyło i dotyczy wyjątkowych wydarzeń, które maja wpływ na obrót ekonomiczno-prawny, do których należy zaliczyć m.in. wojny, klęski żywiołowe, rewolucje czy kryzysy gospodarcze. Należy zaznaczyć, że moratoria obejmują wykonanie zobowiązań zarówno publicznoprawnych, jak i prywatnoprawnych. Do pierwszej grupy należy zaliczyć przede wszystkim szeroko rozumiane daniny publicznoprawne, które stanowią dochód budżetu państwa, w tym jednostek prawa publicznego. W przypadku zobowiązań publicznoprawnych działalność legislacyjna państwa zwykle ma postać całkowitego lub częściowego umorzenia należności pieniężnych, w tym prolongowania terminu ich płatności często przy rozłożeniu zapłaty na raty. Warto jednak zaznaczyć, że państwo nie może w zasadzie zrezygnować z ich całkowitego umorzenia ze względu na konieczność utrzymania stabilności finansowej, co wiąże się z zaspokajaniem jego potrzeb budżetowych.

W przypadku zobowiązań prywatnoprawnych państwo niejako staje się „rozjemcą”, wydaje bowiem unormowania prawne, których celem jest udzielenie dłużnikowi moratorium, na podstawie określonych aktów prawnych lub upoważnia do tego sądy, w tym specjalnie powołane urzędy. Ponadto rozwiązanie zaciagniętych uprzednio umów w okresie przed wystąpieniem nadzwyczajnych wydarzeń, w tym wzajemny zwrot dokonanych świadczeń przez strony, może zostać oparty na klauzuli rebus sic stantibus, o ile w systemie prawnym określonego państwa jest przewidziana tego 
rodzaju klauzula, która stanowi odejście od zasady pacta sunt servanda [Jastrzębski, 2009, s. 394 i n.].

\section{Kryzys gospodarczy lat 30. i polityka deflacyjna państwa polskiego}

Kryzys gospodarczy, który wybuchł w 1929 r., stanowił w wielu gospodarkach odejście od liberalnej polityki na rzecz interwencjonizmu państwowego oraz wzrost zjawisk autarkicznych i etatyzmu w poszczególnych państwach. Istotne znaczenie miał spadek produkcji przemysłowej, który był niespotykany w trakcie wcześniejszych depresji gospodarczych. Wzrost produkcji rolnej natomiast powodował jednocześnie drastyczny spadek cen towarów rolnych, co pogłębiało skalę załamania gospodarczego [Karpiński, 1968, s. 122 i n.; Landau, Tomaszewski, 1982, s. 30 i n.; Morawski, 2003, s. 109 i n.]. W związku z tym miały miejsce m.in. powszechny spadek cen, bezrobocie oraz problemy w obrocie międzynarodowym. W przypadku państwa polskiego kryzys miał przede wszystkim charakter rolny, co wynikało ze struktury gospodarczej II Rzeczypospolitej, której około 70\% społeczeństwa utrzymywało się z produkcji rolniczej. Konsekwencja tego był spadek dochodowości gospodarstw rolnych.

Warto zaznaczyć, że na początku zwracano powszechnie uwagę na to, iż kryzys ma charakter przejściowy i będzie trwał zaledwie kilka lat. $\mathrm{W}$ praktyce niewielkie polepszenie koniunktury w rolnictwie nastąiło dopiero w 1936 r. [Drozdowski, 1963, s. 15 i n.; Landau, Tomaszewski, 1982, s. 154 i n.; Landau, Tomaszewski, 1989, s. $237 \mathrm{i} \mathrm{n.].} \mathrm{Istotne} \mathrm{znaczenie} \mathrm{dla} \mathrm{przebiegu} \mathrm{kryzysu} \mathrm{oraz} \mathrm{prowadzonej} \mathrm{polityki}$ antykryzysowej miało wysokie zadłużenie gospodarstw rolnych, które wynikało głównie z: odbudowy gospodarstw rolnych po pierwszej wojnie światowej; reformy rolnej, w związku z którą chłopi zaciągali pożyczki na zakup ziemi; panującej na polskiej wsi lichwy oraz złej organizacji kredytu [Knakiewicz, 1967, s. 60 i n.]. Zadłużenie na polskiej wsi, jak się szacuje na 1931/1932 r., wynosiło około 5 miliardów złotych, przy czym przeciętne zadłużenie na 1 hektar ziemi wynosiło około 200 zł, co stanowiło około 20-25\% cen ziemi [Mieszczankowski, 1983, s. 315]. Powodowało to, że zadłużenie rolnictwa iunctim z drastycznym spadkiem cen towarów rolnych stanowiły w praktyce największy problem ówczesnego państwa polskiego.

Polityka antykryzysowa ówczesnych państw zależała od przyjętej strategii gospodarczej. Znaczenie miało przede wszystkim przeprowadzenie w wielu państwach dewaluacji walut, która polegała na obniżeniu przez państwo kursu pieniędzy w stosunku do parytetu złota i, co za tym idzie, walut obcych. W II Rzeczypospolitej, ze względu na doświadczenia okresu inflacji marki polskiej, obawiano się tej operacji. W związku z tym została przyjęta odmienna koncepcja walki z kryzysem gospodarczym, którą była deflacja [Landau, Tomaszewski, 1982, s. 244 i n.]. Przyjęta przez ówczesne rządowe koła gospodarcze strategia polegała w szczególności na utrzymaniu stałości pieniądza polskiego, zgodnie z parytetem określonym w 1927 r. w wyniku tzw. drugiej stabilizacji złotego [Karpiński, 1968, s. 101 i n.]. Według F. Zweiga [1933, s. 20-21] polityka ta była przede wszystkim ukierunkowana „na 
utrzymanie waluty bezwzględnie ustabilizowanej i dostosowanie reszty elementów życia gospodarczego do wymogów tej stabilizacji walutowej”. W związku z tym do najważniejszych atrybutów tak pojętego programu gospodarczego zaliczył on przede wszystkim ,redukcję budżetu, redukcję uposażeń i płac, redukcję importu, szeroko zakreśloną akcję oddłużenia, wyrównywanie cen przemysłowych i rolnych przez obniżkę cen kartelowych i monopolowych, rewizję obciążeń publicznych i socjalnych, rewizję sztywnych składników kosztów produkcji itd. Jednem słowem, dostosowanie całego życia gospodarczego do nowej wartości pieniądza”. Podobnie w latach 60. definiowała tę strategię ekonomiczną Z. Knakiewicz [1967, s. 26], która stwierdziła, że: ,przez politykę deflacyjną rozumiem politykę równania w dół, dobór środków podporządkowanych ochronie stałości pieniądza i to zarówno środków wzmacniających proces deflacji, jak i środków usuwających i łagodzących dysproporcje powstałe w równowadze gospodarczej w toku przebiegu procesu deflacyjnego". Wynika z tego, że zasada utrzymania nienaruszalności należności pieniężnej, w przypadku zarówno zobowiązań publicznoprawnych, jak i prywatnoprawnych, stanowiła podstawowe założenie polskiego ustawodawstwa antykryzysowego.

Polityka deflacyjna państwa polskiego miała trwać, w pierwotnym założeniu, krótko i jej celem było po prostu przetrwanie złej koniunktury gospodarczej. W praktyce jednak była stosowana, według Z. Knakiewicz, od 1930 do końca 1935 r., przy czym trudno było ustalić ściśle początek i jej zakończenie. Obejmowała ona zasadniczo dwa podokresy, tj. pierwszy od 1930 r. do połowy 1932 r. oraz drugi od połowy 1932 r. do końca 1935 r. Cezurę stanowiła tzw. akcja finansowo-rolna, którą rozpoczęto w drugiej połowie 1932 r. [Knakiewicz, 1967, s. 123 i n.]. Jeśli chodzi o spłatę zobowiązań pieniężnych, polityka deflacyjna oznaczała nominalizm, czyli dłużnicy musieli regulować należności pieniężne w tej samej kwocie, mimo zwiększonej siły nabywczej złotego. W ten sposób, według amerykańskiego ekonomisty I. Fishera [1934, s. 14], miał miejsce tzw. wielki paradoks, gdyż: ,im więcej dłużnik płaci, tem więcej jest winien, spłata bowiem zadłużenia nie może dotrzymać kroku spadkowi cen, który ja powoduje”. Dlatego im więcej dłużnik czynił starań w celu regulowania swoich należności, tym bardziej pogrążał się w zadłużeniu. W związku z tym ówczesne państwo polskie zostało niejako ,zmuszone” do interwencji na drodze legislacyjnej w zakresie spłaty należności pieniężnych.

\section{Ustawodawstwo moratoryjne państwa polskiego}

Regulacje moratoryjne lat 30., które wchodziły w skład szeroko pojętego ustawodawstwa antykryzysowego, dotyczyły przede wszystkim unormowań wydawanych przez władzę wykonawczą. Były to bowiem głównie rozporządzenia Prezydenta Rzeczypospolitej, a następnie - po wejściu w życie Konstytucji Kwietniowej [Ustawa, 1935] - dekrety. Ponadto istotną rolę w ich realizacji odegrały akty niższej rangi, tj. rozporządzenia, zarządzenia, okólniki wykonawcze. Warto zaznaczyć, że miały one w przeważającej mierze charakter administracyjny, a ingerencja ustawodawcy ograniczała się w praktyce do zmiany warunków zapłaty należności pienięż- 
nej oraz wysokości odsetek. W ten sposób dłużnikom przyznawano de facto moratorium, które było cały czas przedłużane. Dotyczyło to przede wszystkim zobowiązań prywatnoprawnych, które miały charakter długów rolniczych, oraz należności pieniężnych zabezpieczonych na nieruchomościach miejskich.

Ustawodawstwo antykryzysowe dotyczyło także publicznoprawnych należności pieniężnych. Co istotne, ich spłata była egzekwowana przez państwo w pierwszej kolejności, gdyż zabezpieczały one dochody budżetowe państwa polskiego. W ten sposób występowały zaległości głównie w podatkach państwowych, opłatach samorządowych, w świadczeniach socjalnych. Szacuje się, że zaległości z tytułu świadczeń publicznoprawnych w 1934 r. wynosiły około $1380 \mathrm{mln}$ złotych [Landau, Tomaszewski, 1982, s. 272-273]. W związku z tym były wydawane akty prawne, które miały na celu odraczanie i rozkładanie na raty, w tym umarzanie w części lub całości zaległości określonych podatków państwowych oraz składek i opłat na rzecz instytucji ubezpieczeń społecznych.

W okresie kryzysu gospodarczego lat 30. istotne znaczenie miało oddłużenie samorządu terytorialnego, które wynikało przede wszystkim z ograniczenia źródeł dochodów związków samorządu terytorialnego, obsługi zadłużenia pochodzącego nawet jeszcze sprzed pierwszej wojny światowej oraz nałożenia na samorząd przez państwo obowiązków bez źródła ich pokrycia finansowego [Oddlu̇̌enie samorz̨adu terytorialnego..., 1937; Zawadzki, 1971, s. 189 i n.]. Zadłużone były głównie miasta oraz powiatowe związki samorządowe. Ciężar ogólnego zadłużenia w 1934 r. wynosił, nie wliczając zadłużenia Warszawy, $1154 \mathrm{mln}$ złotych, przy czym indywidualną akcją oddłużenia objęto zobowiązania w wysokości 1094 mln złotych. W przeważającej większości były to wierzytelności publicznoprawne, na które przypadało 922 mln złotych [Zawadzki, 1971, s. 223]. W związku z tym została podjęta akcja oddłużeniowa, która objęła niemal wszystkie związki samorządu. Początkowo akcja oddłużeniowa miała charakter antyegzekucyjny, a następnie polegała na konwersji zobowiązań krótkoterminowych na długoterminowe, odroczeniu spłaty długów hipotecznych o obniżonym oprocentowaniu w stosunku rocznym, powołaniu komisji oszczędnościowo-oddłużeniowych dla samorządu, które funkcjonowały przy urzędach wojewódzkich, oraz Centralnej Komisji Oszczędnościowo-Oddłużeniowej dla Samorządu przy Prezesie Rady Ministrów i Urzędu Rozjemczego do Spraw Kredytowych Samorządu Terytorialnego z siedzibą w Warszawie [Rozporządzenie, 1932a; Rozporządzenie, 1934]. Zakończenie akcji oddłużeniowej nastapiło w połowie 1937 r. [Ustawa, 1937]. W jej rezultacie miała miejsce redukcja zadłużenia związków samorządowych na około 30\%, przy czym dotyczyła ona należności pieniężnych tzw. wierzycieli publicznych, tj. instytucji państwowych oraz komunalnych instytucji kredytowych [Ostrowski, 1962, s. 321]. W stosunku do pozostałych wierzycieli zostały ustalone korzystniejsze warunki spłaty należności pieniężnych, co w praktyce oznaczało moratorium.

Ustawodawstwo moratoryjne $\mathrm{w}$ zakresie zobowiązań prywatnoprawnych było zwiazzane przede wszystkim $\mathrm{z}$ rolniczym ustawodawstwem antykryzysowym. W szczególności dotyczyło ono oddłużenia rolnictwa, które należy podzielić na cztery wyraźne etapy, przy czym ostatni nie został zakończony. Pierwszy - obejmujący 
ustawy z lutego, marca oraz czerwca 1932 r. - miał na celu głównie zahamowanie licytacji gospodarstw rolnych. Kolejny - od sierpnia 1932 r., był związany z zawieraniem układów przez urzędy rozjemcze i Bank Akceptacyjny. Trzeci, od października 1934 r., charakteryzował się prawnym obniżeniem stopy procentowej oraz rozłożeniem na szereg lat spłaty zobowiązań pieniężnych. Ostatni etap z 1938-1939 r. został przerwany przez wybuch drugiej wojny światowej [Drozdowski, 1963, s. 222-231; Mieszczankowski, 1983, s. 329 i n.; Jastrzębski, 2009, s. 271 i n.]. Warto zaznaczyć, że w Dzienniku Ustaw regulacje prawne dotyczące oddłużenia gospodarstw wiejskich były szacowane na 74 pozycje [Rusinek, 1939, s. 115], przy tym stanowiły one jedynie ramy dla całej rolniczej akcji oddłużeniowej. O jej przebiegu bowiem decydowały w dużej mierze liczne zarządzenia, okólniki, pisma, regulaminy itp. W związku z tym zostało nawet wydane w 1936 r. opracowanie pod tytułem Kodeks ulg rolniczych [Richter i in., 1936].

Ze względu na stosunki kredytowe akcja oddłużeniowa w rolnictwie obejmowała tzw. rynek zorganizowany, w których kredytodawcą była instytucja kredytowa, tj. banki, kasy, towarzystwa kredytowe itp., oraz rynek niezorganizowany. W przypadku pierwszego $z$ nich ingerencja państwa w praktyce miała charakter administracyjny. Państwo bowiem udzielało pomocy instytucjom finansowym, które przyznały kredyty rolnictwu, w szczególności dotyczyło to kredytów krótkoterminowych. W związku z tym został uruchomiony Bank Akceptacyjny, który pośredniczył w zawieraniu tzw. układów konwersyjnych między określoną instytucją kredytową a dłużnikiem. Polegały one na konwersji krótkoterminowych kredytów na średnioterminowe albo długoterminowe przy obniżonej stopie procentowej [Knakiewicz, 1967, s. 266 i n.; Karpiński, 1958, s. 146 i n.; Morawski, 1998, s. 53-55]. $\mathrm{Na}$ ich podstawie Bank Akceptacyjny udzielał instytucji kredytowej pomocy finansowej m.in. w postaci nisko oprocentowanego kredytu oraz pokrycia części strat, które ponosiła taka instytucja w związku z nieściagalnością wierzytelności objętej układem. Ponadto oddłużenie rolnictwa dotyczyło działalności innych banków, np. Państwowego Banku Rolnego [Mieszczankowski, 1983, s. 331-332].

Rynek niezorganizowany dotyczył przede wszystkim działalności urzędów rozjemczych, które zostały powołane na podstawie rozporządzenia Prezydenta Rzeczypospolitej z 1932 r. o utworzeniu urzędów rozjemczych do spraw kredytowych małej własności rolnej [Rozporządzenie, 1932b], które następnie zostało uchylone przez ustawę z dnia 28 marca 1933 r. [Ustawa, 1933]. Urzędy rozjemcze stanowiły sui generis organy administracyjne, które rozstrzygały sprawy z zakresu prawa cywilnego. Orzeczenia urzędów i zawarte przed nimi ugody miały charakter wyroków sądowych. Właściwość urzędów obejmowała m.in. obniżenie wysokości pobieranych odsetek przez wierzycieli, rozkładanie spłaty już wymagalnych należności pieniężnych oraz określania ich terminu płatności, w tym wysokości rat, wstrzymywanie wyznaczonej już licytacji, ustalania faktycznie pobieranych odsetek przez wierzyciela, które były nadmierne, i zarachowanie ich na poczet spłaty długu. Wynika z tego, że urzędy rozjemcze miały za zadanie przede wszystkim rozłożenie prywatnych długów na raty, przy odpowiednim obniżeniu oprocentowania i wstrzymaniu egzekucji gospodarstw rolnych, oraz przeciwdziałanie lichwie pieniężnej 
i towarowej na polskiej wsi. Warto zaznaczyć, że urzędy stanowiły w pewnym sensie wyłom w ówczesnym wymiarze sprawiedliwości w stosunku do zadłużonych mieszkańców wsi, który był wykonywany przez sądy powszechne. Z właściwości bowiem tych ostatnich zostały wyłączone sprawy z zakresu długów o charakterze rolniczym [Majewski, 1960; Jastrzębski, 2009, s. 354-373].

Moratoria objęły także spłatę należności pieniężnych, które były związane z kredytem długoterminowym zarówno wiejskim, jak i miejskim. Interwencja ówczesnego ustawodawcy miała, podobnie jak w przypadku rolnictwa, charakter stopniowy, tj. antyegzekucyjny, a następnie moratoryjny. Analogicznie też objęła rynek zorganizowany oraz niezorganizowany. W przypadku pierwszego $z$ nich polegała na konwersji pożyczek emisyjnych, w tym związanych z nimi listów zastawnych, oraz obligacji przy obniżonym oprocentowaniu. Jeśli zaś chodzi o rynek niezorganizowany, miała na celu zmianę terminu wymagalności należności pieniężnych, zabezpieczonych hipotecznie, również przy obniżonym oprocentowaniu Jastrzębski, 2009, s. 309-318].

\section{Podsumowanie}

Prawo moratoryjne II Rzeczypospolitej w okresie wielkiego kryzysu gospodarczego lat 30 . miało przede wszystkim na celu udzielenie pomocy rolnictwu ze względu na drastyczny spadek cen towarów rolnych. Determinowała je przyjęta przez ówczesne rządy pomajowe strategia gospodarcza, tj. polityka deflacyjna. Dlatego udzielane moratoria miały charakter okresowy i były stopniowo wprowadzane wraz z nasilaniem się ujemnych skutków kryzysu. W ten sposób ustawodawca stanął w obronie praw dłużników - głównie rolników, którzy nie mogli wywiązać się z zaciagniętych wcześniej zobowiazzań pieniężnych. Celem tego działania było przywrócenie zdolności nabywczej rolnictwa [Karpiński, 1968, s. 142]. Warto zaznaczyć, że regulacje antykryzysowe, w tym moratoryjne, były liczne. W związku z tym w końcu grudnia 1934 r. H. Tennenbaum [1935, s. 448] wprost określił je mianem „gęstwiny scholastycznej”, dodając, iż „od szeregu prawników słyszałem, że trudno się w tem rozeznać".

Unormowania moratoryjne, zwłaszcza w odniesieniu do zobowiązań prywatnoprawnych, stanowiły ingerencje państwa polskiego w stosunki między dłużnikiem a wierzycielem i, co za tym idzie, naruszały zasady prawa, takie jak: pacta sunt servanda, lex retro non agit, redde quod debes. Wynika z tego, że państwo w okresie kryzysu sięgało do całego arsenału środków prawnych, których głównym celem była realizacja przyjętej strategii gospodarczej w myśl zasady necessitas non habet legem. Zastosowana polityka nie spowodowała obniżenia ogólnego zadłużenia rolnictwa. Obniżyła jednak koszty obsługi, tj. wysokość odsetek, oraz rozłożyła spłatę należności pieniężnych na szereg lat. Co istotne, ustawodawstwo moratoryjne objęło w praktyce tylko rolnictwo. W ten sposób pozostałe grupy społeczne były niejako poza nawiasem ustawodawstwa antykryzysowego, ti. nie znalazły się pod opieką ustawodawstwa państwa polskiego, w szczególności chodziło o kupiectwo (handel) oraz przemysł. 
Wybuch drugiej wojny światowej spowodował, że spłata należności pieniężnych objętych ustawodawstwem moratoryjnym została odłożona w czasie. Ostatecznie zagadnienie to unormował, notabene obowiązujący współcześnie, dekret z 1949 r. [Dekret, 1949]. Zgodnie z dekretem spłata należności z zobowiązań pieniężnych, które powstały z jakiegokolwiek tytułu publicznoprawnego lub prywatnoprawnego przed jego wejściem w życie, mogła nastąpić w pieniądzu polskim, tj. biletach Narodowego Banku Polskiego według ich wartości nominalnej, przy czym nie miało znaczenia, jaki środek płatniczy opiewający na złote obiegał w chwili powstania zobowiązania. Ponadto zmiana siły nabywczej pieniądza w czasie między powstaniem zobowiązania a jego wymagalnościa lub wykonaniem nie stanowiła podstawy do zmiany wysokości świadczenia. W ten sposób nowa władza ludowa wprowadziła zasadę nominalizmu pieniężnego, która była korzystna dla dłużników.

Prawo moratoryjne państwa polskiego w okresie kryzysu gospodarczego lat 30 . realizowało przyjętą przez ówczesną władzę strategię polityki deflacyjnej. Jej celem była obrona za wszelką cenę ustabilizowanej w 1927 r. polskiej waluty, a także błędne założenie o krótkotrwałym przesileniu gospodarczym. Moratoria były stosowane przede wszystkim wobec ludności rolniczej, czyli około 70\% społeczeństwa, co wynikało ze struktury gospodarczej ówczesnego państwa polskiego. Oczywiście pytaniem bez odpowiedzi pozostanie, czy zastosowanie innej strategii gospodarczej, bardziej radykalnej, byłoby korzystniejsze w ówczesnej sytuacji ekonomicznej. Chodzi głównie o dewaluację złotego, która objęłaby całe społeczeństwo II Rzeczypospolitej, tzw. inflacyjne nakręcanie koniunktury gospodarczej oraz redukcję zadłużenia, przede wszystkim długów rolniczych [Knakiewicz, 1967, s. 104 i n.; Karpiński, 1968, s. 131 i n.]. W praktyce jednak nie zastosowano żadnej z wyżej wymienionych metod. Warto podkreślić, że ustawodawstwo moratoryjne uprzywilejowało jedną grupę społeczeństwa - zadłużonych rolników, koszty zaś tego ponosili ich wierzyciele. Spłata należności pieniężnych bowiem została rozłożona na szereg lat przy obniżonej stopie odsetek. Trafnie regulacje moratoryjne określił w 1937 r. Wł. Grabski [1937, s. 18], który uznał, że były one „wyrafinowanym sposobem wywłaszczenia wierzycieli z posiadanego przez nich majątku”, co w praktyce ostatecznie nastapiło po zakończeniu drugiej wojny światowej, ale już w innej sytuacji polityczno-ekonomicznej.

\section{Literatura}

Dekret, 1949, Dekret z dnia 27 lipca 1949 r. o zaciaganiu nowych i określaniu wysokości nieumorzonych zobowiązań pieniężnych, Dz.U. 1949, Nr 45, poz. 332.

Drozdowski M., 1963, Polityka gospodarcza rzqdu polskiego 1936-1939, Państwowe Wydawnictwo Naukowe, Warszawa.

Fisher I., 1934, Teorja deflacji dtugów w wielkich kryzysach, Towarzystwo Ekonomiczne, Kraków.

Glass J., 1930, Moratorjum, [w:] Encyklopedja Podręçna Prawa Publicznego (konstytucyjnego, administracyjnego $i$ miedzynarodowego), Cybichowski Z. (red.), t. I, Instytut Wydawniczy „Bibljoteka Polska”, Warszawa. 
Grabski W., 1937, Reforma oddlušenia rolniczego na skutek warostu cen rolniçych, „Przegląd Ekonomiczny", t. XVII, s. 3-20.

Jastrzębski R., 2009, Wplyw sity nabywczej pieniadza na wykonanie zobowiazań prywatnoprawnych w II Rzeczypospolitej, Wolters Kluwer Polska, Warszawa.

Karpiński Z., 1958, Bank Polski 1924-1939, Polskie Wydawnictwa Gospodarcze, Warszawa.

Karpiński Z., 1968, Ustroje pienię̇ne w Polsce od roku 1917, Państwowe Wydawnictwo Naukowe, Warszawa.

Knakiewicz Z., 1967, Deflacja polska 1930-1935, Państwowe Wydawnictwo Ekonomiczne, Warszawa.

Landau Z., Tomaszewski J., 1982, Wielki Krysys 1930-1935. Gospodarka Polski Mięrywojennej 1918-1939, t. III, Książka i Wiedza, Warszawa.

Landau Z., Tomaszewski J., 1989, Lata Interwencionizmu Państwowego 1936-1939. Gospodarka Polski Międrywojennej 1918-1939, t. IV, Książka i Wiedza, Warszawa.

Liebeskind A., 1935, Moratorjum, [w:] Encyklopedja Podreczna Prawa Prywatnego założona przez Henryka Konica, Zoll F., Wasilkowski J. (red.), t. II, Bibljoteka Polska, Warszawa.

Majewski J., 1960, Struktura i rola urzędón roßjemcsych do spraw majatkonych posiadaçy gospodarstw wiejskich w latach 1932-1939, „Roczniki Dziejów Społecznych i Gospodarczych", t. XXII, s. 109-163.

Mieszczankowski M., 1983, Rolnictwo II Ržeczypospolitej, Książka i Wiedza, Warszawa.

Morawski W., 1998, Stownik bistoryczny bankowości polskiej do 1939 roku, Muza, Warszawa.

Morawski W., 2003, Kronika kryzysów gospodarcsych, Trio, Warszawa.

Oddhużenie samorzadu terytorialnego. Sprawozdanie Centralnej Komisji Osžczędnościowo-Oddtużeniowej dla Samorzadu, 1937, Warszawa.

Ostrowski K., 1962, Finanse i prawo finansowe, [w:] Historia Panstwa i Prawa Polski 19181939, Bardach J. (red.), Państwowe Wydawnictwo Naukowe, Warszawa.

Richter M., Zarwincer P., Korczemny W., 1936, Kodeles Ulg Rolnicsych. Komentar: Teksty ustaw i rozporzadzeń - przepisy zwiazkowe, Księgarnia Powszechna, Kraków.

Rozporządzenie, 1932a, Rozporząqdzenie Prezydenta Rzeczypospolitej z dnia 27 października 1932 r. o dochodzeniu roszczeń pieniężnych, opartych na tytułach prywatno-prawnych, przypadających od związków komunalnych, Dz.U. 1932, Nr 94, poz. 809.

Rozporządzenie, 1932b, Rozporządzenie Prezydenta Rzeczypospolitej z dnia 23 sierpnia 1932 r. o utworzeniu urzędów rozjemczych do spraw kredytowych małej własności rolnej, Dz.U. 1932, Nr 72, poz. 653.

Rozporządzenie, 1934, Rozporządzenie Prezydenta Rzeczypospolitej z dnia 24 października 1934 r. o poprawie gospodarki i finansów związków samorządowych, Dz.U. 1934, Nr 94, poz. 846.

Rusinek Z., 1939, Oddłużenie gospodarstw wiejskich, [w:] Encyklopedja Nauk Politycznych (Zagadnienia społeczne, polityczne i gospodarcze), Reyman E.J. (red.), t. I, Wydawnictwo Instytutu Społecznego: Instytut Wydawniczy Bibljoteka Polska, Warszawa. 
Tennenbaum H., 1936, Struktura Gospodarstwa Polskiego, t. II. Kredyt, Instytut Wydawniczy „Bibljoteka Polska”, Warszawa.

Ustawa, 1933, Ustawa z dnia 28 marca 1933 r. o utworzeniu urzędów rozjemczych do spraw majątkowych posiadaczy gospodarstw wiejskich, Dz.U. RP, Nr 29, poz. 253.

Ustawa, 1935, Ustawa Konstytucyjna z dnia 23 kwietnia 1935 r., Dz.U. RP, 1935, Nr 30, poz. 227.

Ustawa, 1937, Ustawa z dnia 29 marca 1937 r. o zakończeniu akcji oddłużenia związków samorządowych, Dz.U. RP, Nr 24, poz. 151.

Zawadzki A.W., 1971, Finanse samorzqadu terytorialnego w latach 1918-1939, Państwowe Wydawnictwo Ekonomiczne, Warszawa.

Zweig F., 1933, O programach walki z kryzysem, Towarzystwo Ekonomiczne, Kraków. 